\title{
Innovative solution of coal slurry mixer
}

\begin{abstract}
During the coal-enrichment process in mechanical processing plants, fine-grained highmoisture coal slurries are produced. These waste products may be used in energetic blends after a special moisture-reducing treatment. Therefore, coal slurry pelletizers are produced (among other things).

In the Department of Mining, Dressing, and Transport Machines, a project of a prototypical installation for coal slurry pelletization with a capacity of $50 \mathrm{Mg} / \mathrm{h}$ was constructed. The main part of the installation is the mixer. At its bottom part, an opening is placed that is closed by a metal plate. During the pelletization work, a plate is halfopening and rotates around its own axis. The rotation of the drum and agitators installed inside the mixer causes sludge grinding and its homogenization. A properly working drum closure system is important for the proper exploitation of the mixer. The designed mechanism allows us to lower the plate linearly in the first phase and then turn it with a predetermined angle after the complete removal of material from the drum. The project required an examination of the kinematics of the system and determination of the drive system load, which allowed us to designate the working parameters. This paper presents the course of the taken actions and results of the fundamental research, along with their analysis. A selection of optimum design and exploitation parameters was performed on the basis of the graphical synthesis method, created simulation model, and tests of the prototype device.
\end{abstract}

Key words: pelletization, agglomeration, mixer, alternative fuels, coal slurries, pellets, granulation, tank closure mechanisms

\section{INTRODUCTION}

During coal-enrichment processes in hard coal mine mechanical processing plants, fine-grained and high-moisture industrial waste is produced, which is called coal slurry. These slurries are the smallest grain classes with a grain size below $1 \mathrm{~mm}$ in which fractions of less than $0.035 \mathrm{~mm}$ represent $60 \%$ of the mass. Depending on the quality parameters (ash and sulfur content, caloric value), the slurries could be addressed directly to an energy mix or deposited in mine ground sedimentation tanks. The high surface moisture of the slurry (within a range of 25 to $30 \%$ after filter dehydration) results in difficulties in unloading the product from wagons, especially in the winter (due to the lack of effective low-cost antifreezing solutions). The most-preferred way to re- duce the moisture content of the coal is a chemical interaction, resulting in a lowered free moisture ratio of the coal slurry. Thus, the prepared energy mix can be subjected to pressure agglomeration [1] or nonpressure agglomeration (pelletization) [2-9]. The preferred solution is to use pelletization due to the lower energy consumption of the process.

In the AGH Department of Mining, Dressing, and Transport Machines, a project of a prototypical installation for coal slurry pelletization (Fig. 1) with a capacity of $50 \mathrm{Mg} / \mathrm{h}$ has been undertaken.

The coal slurry pelletization plant consists of the following components:

- coal slurry feeding system (1),

- mixer (2),

- balling plate (3),

- binding additives delivery system (4),

- product output system (5). 


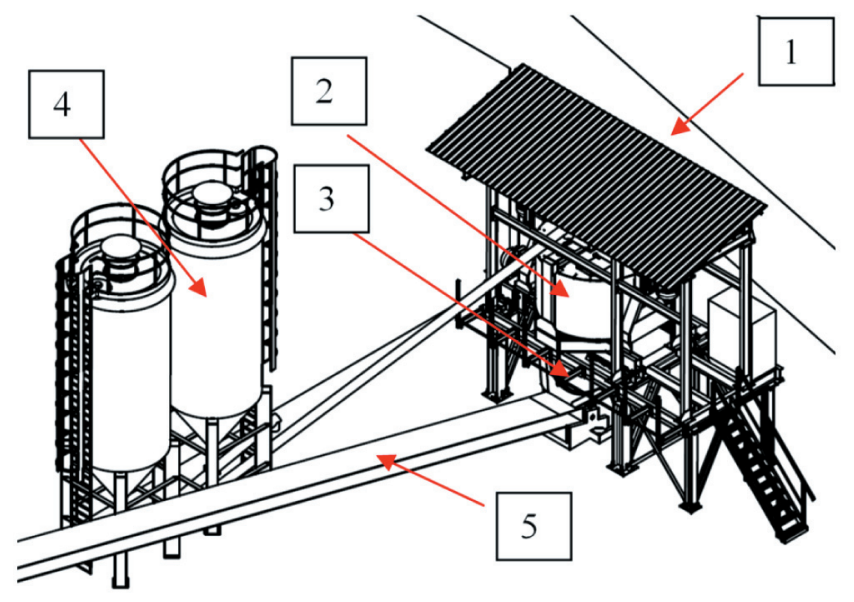

Fig. 1. Coal slurry pelletization station: 1 - coal slurry feeding system; 2 - mixer; 3 - balling plate; 4 - binding additives feeding system; 5 - slurry output conveyor

An essential part of the installation is the mixer (Fig. 2), which is built with a rotating drum with a diameter of $2.7 \mathrm{~m}$ and height of $1.6 \mathrm{~m}$, to which coal sludge is fed along with binding agents (limestone). Inside the mixer, two stirrers with independent drives are installed whose task is to grind the sludge, feed in pieces, and mix it with a special substance fed from the silo by a screw conveyor, which ultimately decreases the moisture of the slurry. In the lower part of the mixing drum, a material output opening is situated; this opening is closed by a plate. During operation, the balling plate is tilted and rotates around its own axis. This system helps in emptying the drum and partially causing a pelletization of the material.

After establishing a steady homogenization process through the inclined plate, the material is fed to the balling disc where is pelletized. After leaving the balling disc, the pelletized material is fed onto a conveyor belt, on which the pelletized slurry is transported to a storage yard. The station's design allows us to add other components to the fuel mixtures produced on the basis of coal sludge or dust. Essential for the proper operation of the mixing system is a properly functioning drum-closing system. In principle, this system should tightly close the container; after opening the locking plate, it should incline to a certain angle of up to $30^{\circ}$. The bearing system limits the size of the drum outlet to $730 \mathrm{~mm}$. This limits the size of the diameter of the locking plate. For proper operation, the locking plate should reduce the discharge area of the material (reducing the risk of mud overhangs). The research shows that the height of this space with the assumed diameter should not exceed $200 \mathrm{~mm}$. In the case of the AGH mixer structure, this causes the necessity of placing the closure plate to a depth of at least $125 \mathrm{~mm}$. These requirements led to the need of designing a system that would allow us to lower the plate linearly in the first step inside the drum, and after passing the discharge opening, to incline at a predetermined angle.
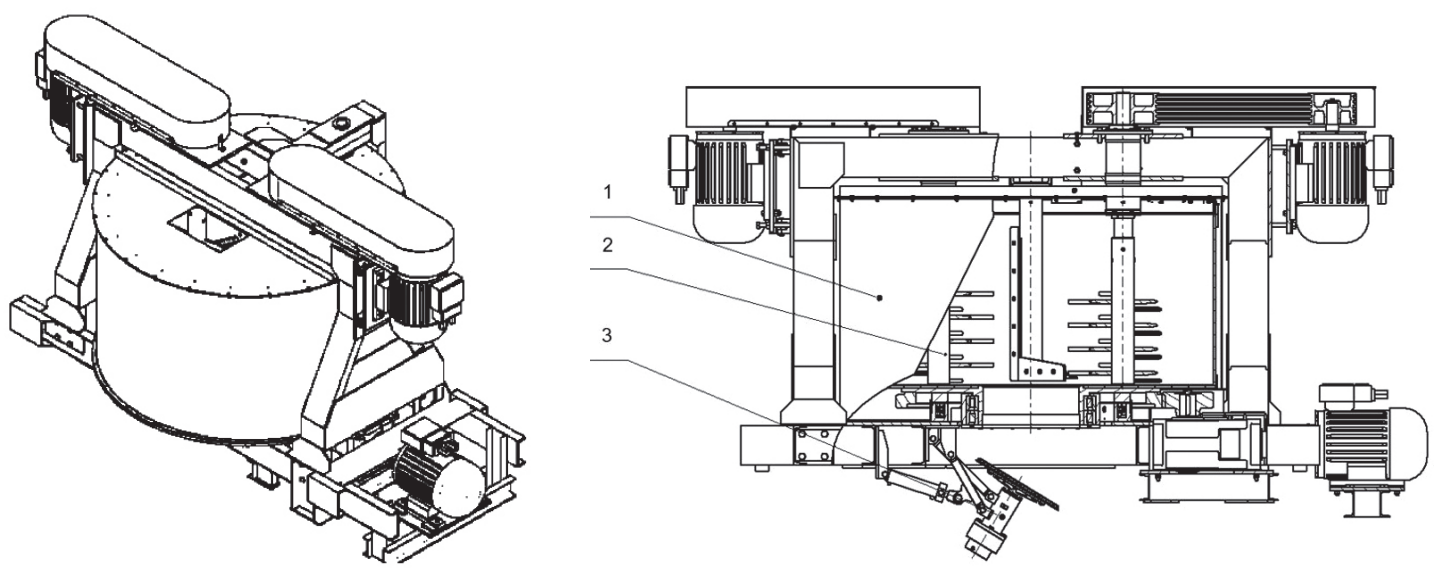

Fig. 2. Coal slurry mixer: 1 - mixer drum; 2 - stirrer arrangement; 3 - drum-closing system 


\section{DETERMINATION OF ARMS' KINEMATIC PARAMETERS}

Knowing the design assumptions (730 mm diameter of the plate, offset from the base of the drum at a min. of $125 \mathrm{~mm}$, a maximum inclination angle of $30^{\circ}$ ), a four-bar linkage system in which different arm lengths $(R, r)$ that are parallel to each other in the raised position was proposed [10]. The first step was to determine the suitable length of the arms so as to not incur a collision between the plate and the opening in the drum mixer. In the design of the mixer, a clearance of $15 \mathrm{~mm}$ between the plate and drum opening was provided, allowing for the free movement of the closing plate.

\subsection{The geometrical calculation of the arm lengths}

Initially, the length of the arms was selected using the graphical synthesis method for the four-bar linkage performing the transition between three set positions (Fig. 3).
Figure 3 shows the arm structure of the analyzed mechanism in accordance with the initially chosen assumptions. The plate's relative displacement to the hole (point T1) does not exceed the established $15 \mathrm{~mm}$. The analysis shows that the upper arm should have a greater length than the bottom one. A length of $620 \mathrm{~mm}$ was chosen for the upper arm, and a $480 \mathrm{~mm}$ length was chosen for the lower one.

\subsection{Verification of system operation correctness}

The proposed four-bar linkage (Fig. 3) allowed us to create a planar model of the closing system that allows us to analyze the kinematics (Fig. 4) [11].

It was assumed that the system would be driven by double-acting hydraulic cylinder, which causes AD element rotation. The starting point to solve the kinematics is given as the following vector equation:

$$
\overline{D A}+\overline{A B}+\overline{B C}=\overline{C D}
$$

where the vector's length is:

$$
R=\overline{B C}, \quad r=\overline{A D}, \quad l=\overline{A B}, \quad d=\overline{C D}
$$

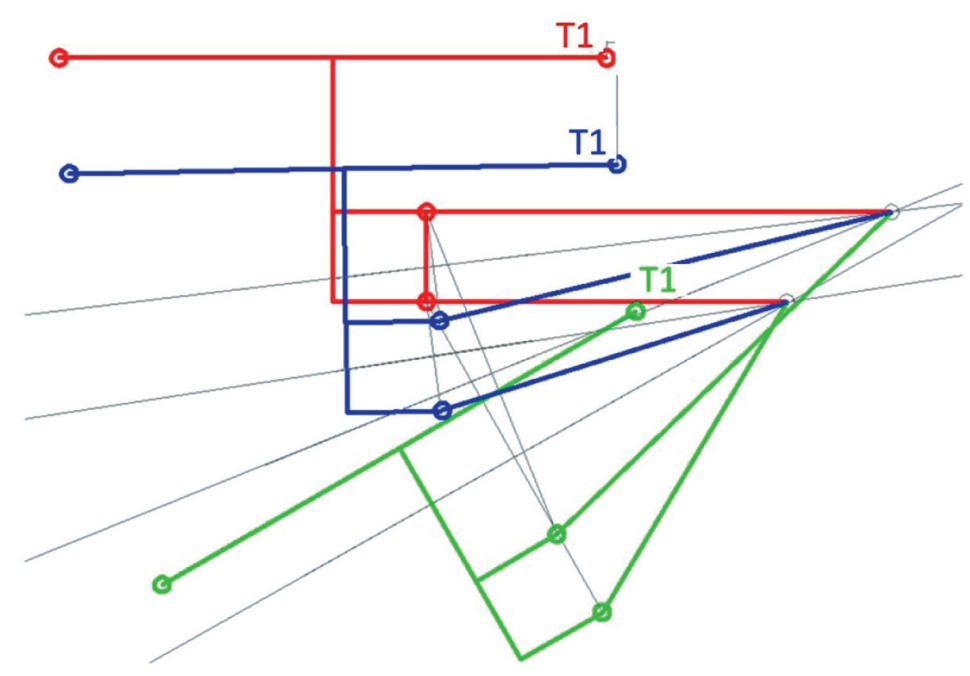

Fig. 3. Four-bar linkage analysis of transition between three set positions: red-drum closed; blue - plate in lower position of drum plane; green - maximum opening and plate inclination

a)

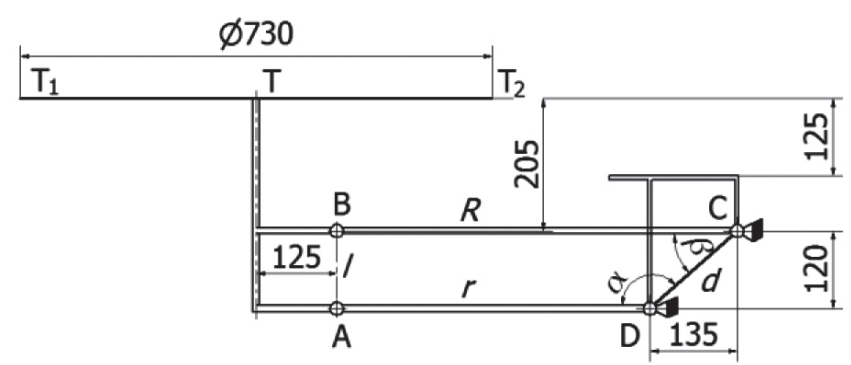

b)

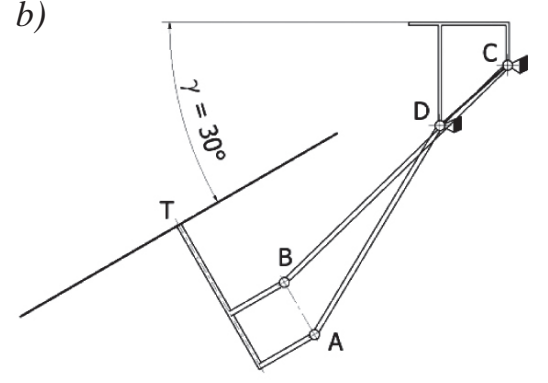

Fig. 4. Planar model of drum-closing system: a) plate in upper position; b) plate in lowered position 
Based on which:

$$
\overline{D A}=\left[\begin{array}{l}
r \cos \alpha \\
r \sin \alpha
\end{array}\right], \quad \overline{B C}=\left[\begin{array}{c}
R \cos \beta \\
-R \sin \beta
\end{array}\right], \quad \overline{C D}=\left[\begin{array}{l}
d \\
0
\end{array}\right]
$$

So, the following can be written:

$$
\overline{A B}^{T} \cdot \overline{A B}=l^{2}
$$

After expansion:

$$
(R \sin \beta-r \sin \alpha)^{2}+(d-R \cos \beta-r \cos \alpha)^{2}=l^{2}
$$

the assembly will be inclined by section $r$, so we assume that the angle is known.

In further considerations, the following substitution will be used:

$$
p=\operatorname{tg} \frac{1}{2} \beta
$$

Equation (3) after using substitution (4) and known trigonometric relationships takes the following form:

$$
\begin{aligned}
& \left(R \frac{2 p}{p^{2}+1}-r \sin \alpha\right)^{2}+ \\
& \quad+\left(d-R \frac{\left(1-p^{2}\right)}{p^{2}+1}-r \cos \alpha\right)^{2}=l^{2}
\end{aligned}
$$

The presented equation has two solutions, from which one that was appropriate to the assumed geometry was chosen (Fig. 4):

$$
\beta=\operatorname{arctg} \frac{\sqrt{K}+2 R r \sin \alpha}{R^{2}+2 R d-2 R r \cos \alpha+d^{2}-2 d r \cos \alpha-l^{2}+r^{2}}
$$

where:

$$
\begin{aligned}
K & =-R^{4}-d^{4}-l^{4}-r^{4}+2 R^{2} d^{2}+ \\
& +2 R^{2} l^{2}+2 R^{2} r^{2}+2 d^{2} l^{2}-4 d^{2} r^{2}+ \\
& +2 l^{2} r^{2}-2 d^{2} r^{2} \cos 2 \alpha+ \\
& +4 d r\left(-R^{2}+d^{2}-l^{2}+r^{2}\right) \cos \alpha
\end{aligned}
$$

Knowing the value of the $\beta$ angle, the position of points $\mathrm{A}$ and $\mathrm{B}$ and value of angle $\gamma$ can be obtained, which allows us to determine point T's trajectory. In Figure 5, the exemplary chart is shown of points A, B, T positions with the assumed center of the coordinate system at point $\mathrm{C}$, with the $\mathrm{x}$ axis oriented horizontally and y axis vertically.

To avoid a collision between the plate and mixer drum, it is important to provide that, during its $125 \mathrm{~mm}$ movement along the y axis, point T2 (Fig. 4) does not move along the $\mathrm{x}$ axis further than the predicted clearance. To verify the design assumptions, a chart location of the three characteristic points of the plate $\left(\mathrm{T}, \mathrm{T}_{1}, \mathrm{~T}_{2}\right.$ ) was made (Fig. 6).

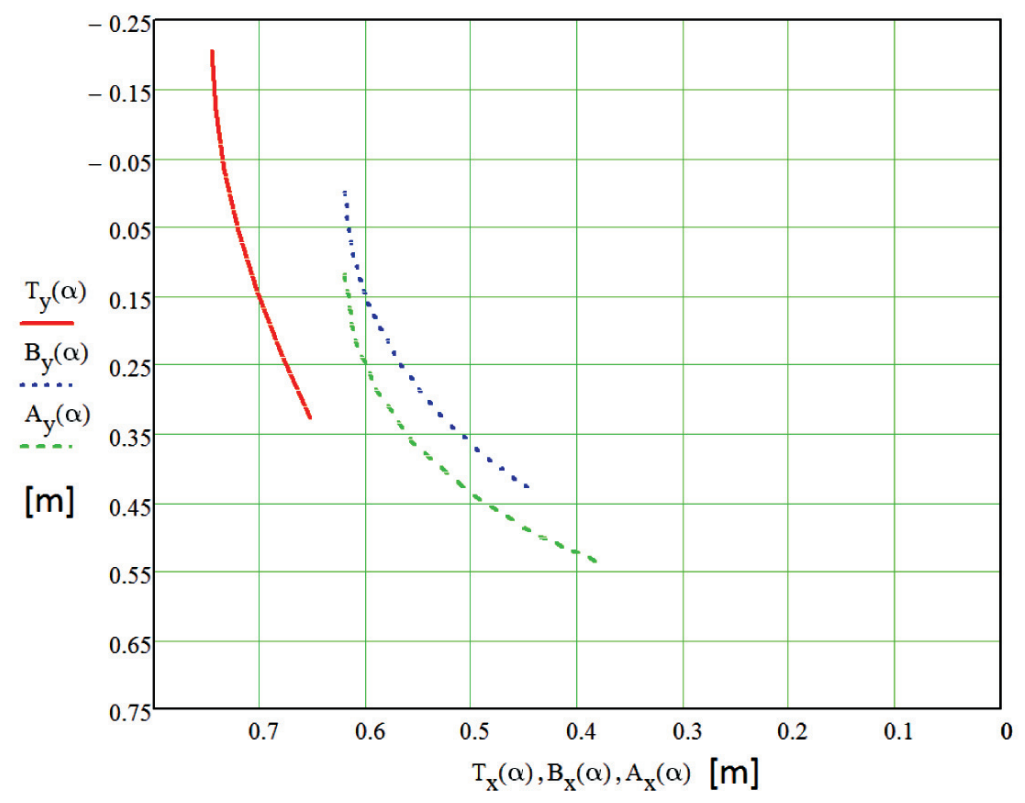

Fig. 5. Exemplary trajectories of points $A, B$ and depending on inclination angle of element $A D(\alpha)$ 


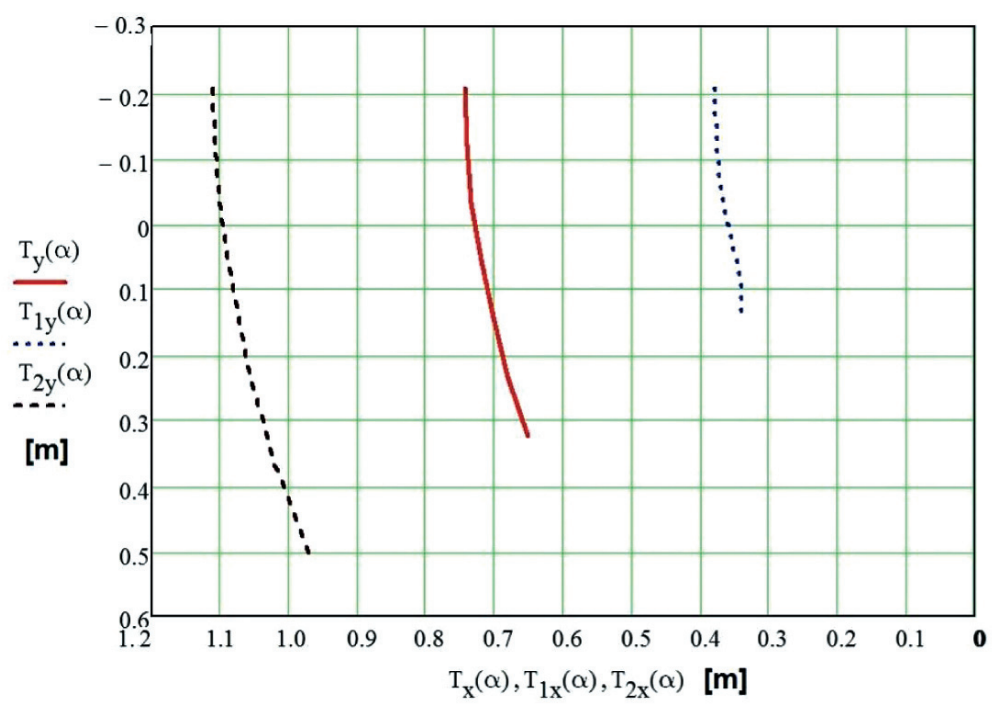

Fig. 6. Trajectories of three characteristic plate points

The position analysis shows that this arrangement meets the kinematic structure expectations. Also, angle $\alpha$ was determined, of which the lower arm should be rotated to achieve the necessary $30^{\circ}$ of plate inclination. This angle was determined on $58^{\circ}$. The next stage of the work was to create a model of the clamping unit (Fig. 7) supplemented with the plate drive system.

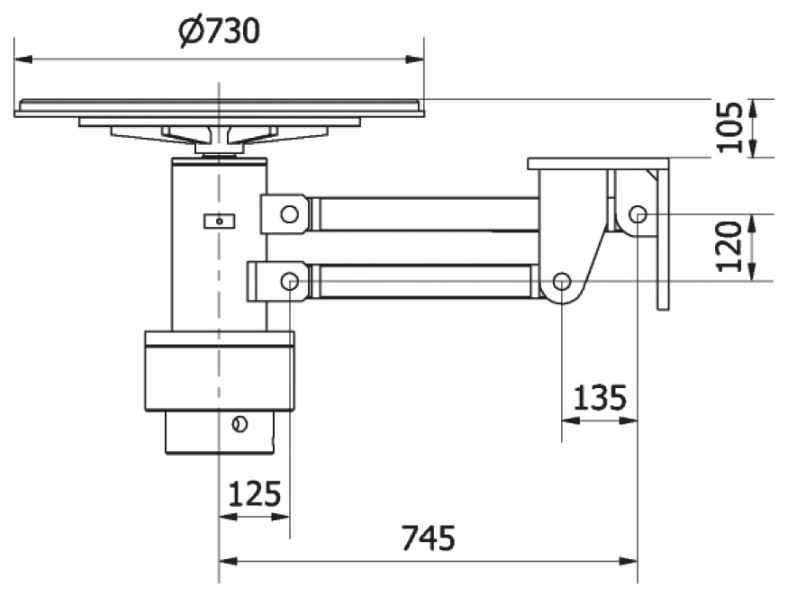

Fig. 7. Drum clamping unit model
For the plate drive, a hydraulic motor with following parameters was selected:

- unit motor absorption: $1000 \mathrm{~cm}^{3} / \mathrm{rev}$,

- nominal pressure: $16 \mathrm{MPa}$,

- maximum pressure: $25 \mathrm{MPa}$,

- nominal torque: $2500 \mathrm{Nm}$,

- maximum rotational speed: $160 \mathrm{rev} / \mathrm{min}$,

- work with the assumed speed in the range of 30-50 rev/min.

\subsection{Model verification for assumed design parameters}

Essential for the system's proper operation is the appropriate design of the lower arm lift. It was assumed that the hydraulic actuator will be used to drive the lower arm. The earlier-created model of the closing system was complemented by a hydraulic cylinder mounted on an additional holder (Fig. 8).

For such a system, the hydraulic cylinder piston stroke should be at least $220 \mathrm{~mm}$ (determined on the basis of a kinematics analysis). On this basis, a hydraulic cylinder with a stroke of $230 \mathrm{~mm}$ was chosen. a)

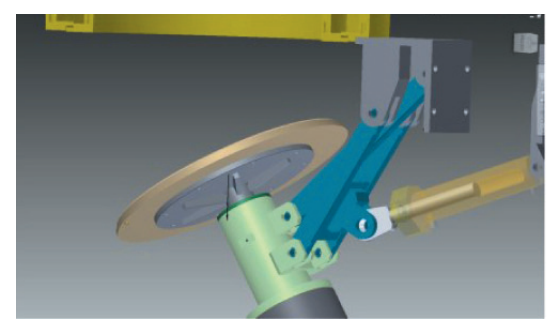

b)

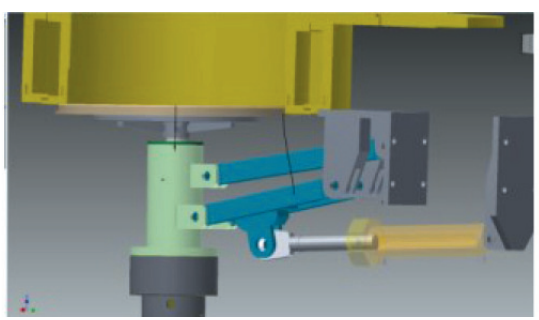

c)

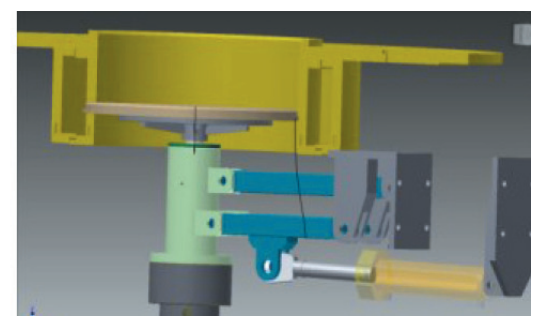

Fig. 8. Drum-closing system model in three stages:

a) open; b) lower plane of drum; c) closed 


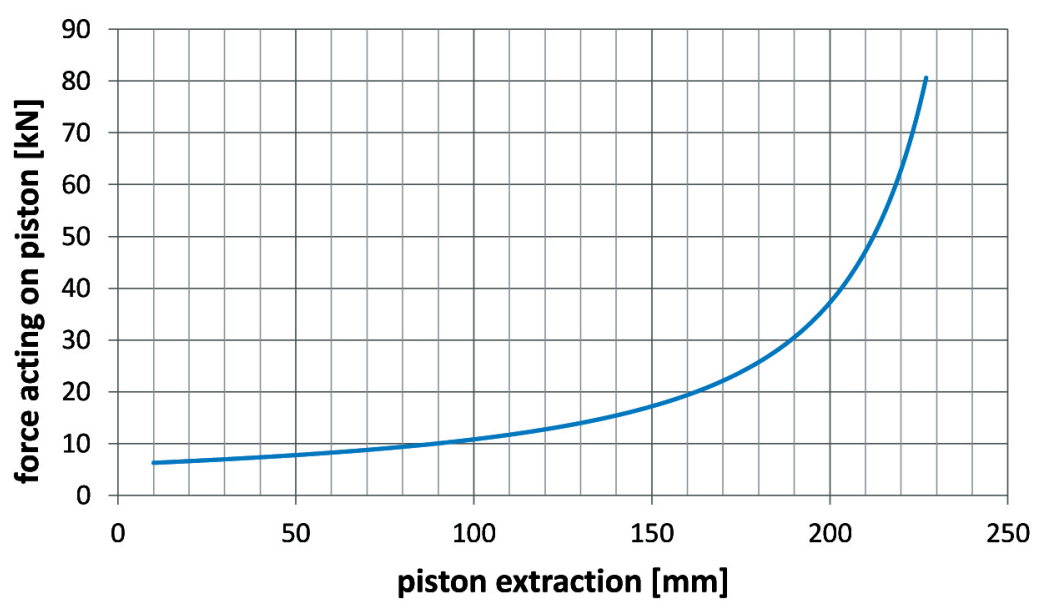

Fig. 9. Value of force acting on piston

In order to determine the remaining parameters of the hydraulic cylinder, the system was subjected to a dynamic analysis. Based on this analysis, the forces acting on the piston of the actuator were determined, assuming the $150 \mathrm{~kg}$ maximum of material load on the plate. During the analysis, a constant rate of piston extension was assumed. On the basis of the simulation, the force acting on the piston versus the degree of extraction were plotted (Fig. 9).

The maximum value of the force acting on the piston occurs at the closing of the drum; this amounts to $80 \mathrm{kN}$. For the designed construction of the plate lifting, a hydraulic cylinder was chosen:

- actuator: hydraulic cylinder $\varnothing 80 / 45$ single-sided double-acting piston rod, mounted on spherical joints,

- active circular piston surface area: $50.30 \mathrm{~cm}^{2}$,

- active ring piston surface area: $34.4 \mathrm{~cm}^{2}$,

- stroke: $230 \mathrm{~mm}$,

- constant speed ejection rod: approx. $4.9 \mathrm{c} / \mathrm{s}$,

- adjustable rod insertion speed: max. approx. $7.1 \mathrm{~cm} / \mathrm{s}$,

- maximum thrust: approx. $80 \mathrm{kN}$ (for $p=16 \mathrm{MPa}$ ),

- required push force during rod ejection: $70 \mathrm{kN}$ (for $p=13.9 \mathrm{MPa}$ ),

- maximum pulling force: approx. $55 \mathrm{kN}$ (for $p=$ $=16 \mathrm{MPa})$,

- required plate-lowering force during rod insertion: $25 \mathrm{kN}(p \approx 5.0 \mathrm{MPa})$.

\section{FIELD TESTS OF THE CLOSING SYSTEM}

On the basis of the prepared documentation, a prototypical device of the coal sludge pelletization system with the proposed closure of the tank was constructed. The first stage of the device's field tests was the plate movement validation. Pictures from the tests are shown in Figure 10.

During the opening and closing of the drum, there were no collisions between the plate and drum (Fig. 10b). Tests have shown that the length of the arms and their mounting points were chosen correctly. The actuator worked properly and without exceeding its technical parameters.

\section{OPERATING NOTES}

The proper work of the rotational plate is conditioned by ensuring adequate lubrication. During the assembly, all bolt and joint mating surfaces must be covered with graphite grease. In Figure 11, the lubrication points are shown. Table 1 shows the location and method of lubrication, type of lubricant, and lubrication timing. a)

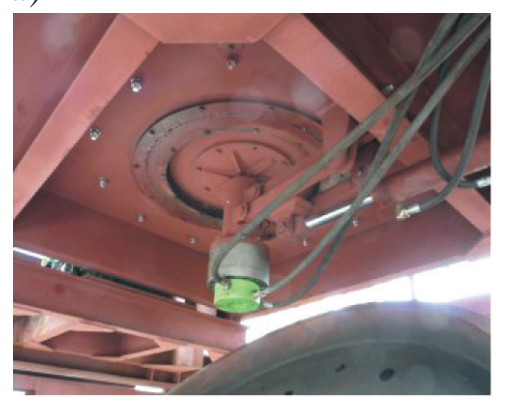

b)

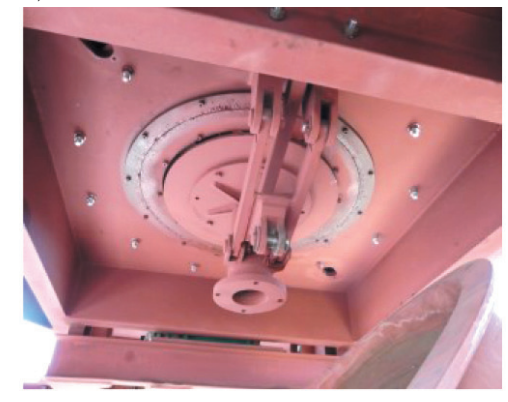

c)

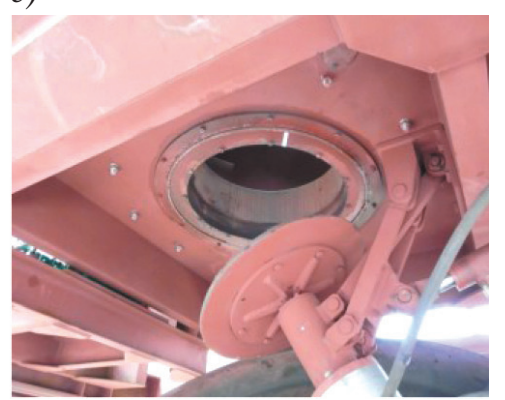

Fig. 10. Mixer closing system: a) in closed position; b) in middle position; c) in open position 


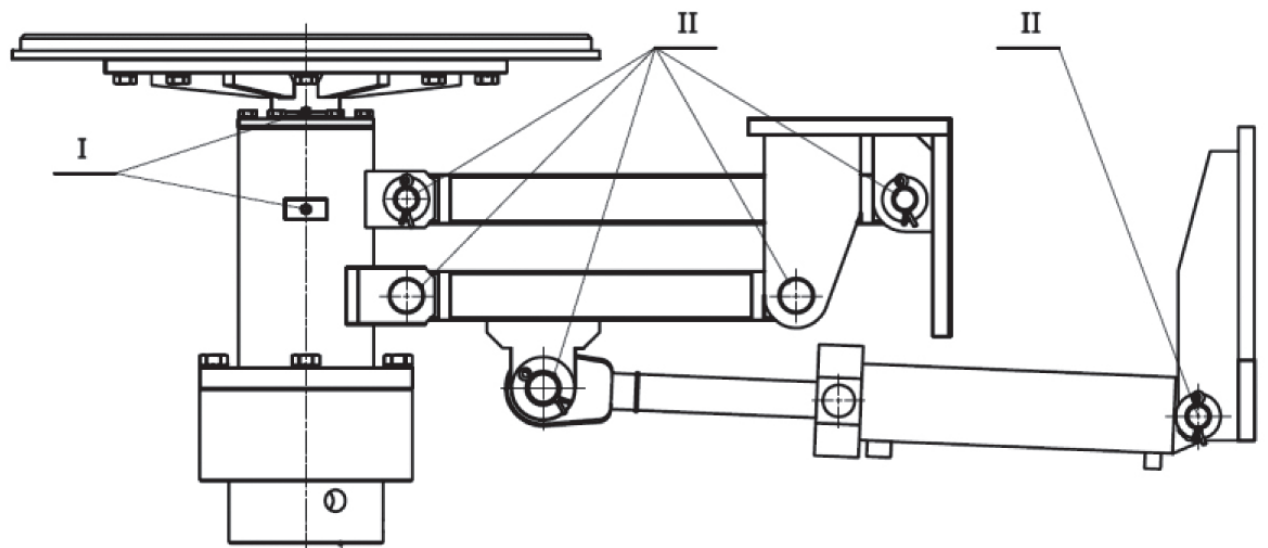

Fig. 11. Location of lubrication points in rotational plate assembly

Table 1

Location and method of rotational plate assembly lubrication

\begin{tabular}{|c|c|c|c|}
\hline $\begin{array}{c}\text { Lubrication } \\
\text { point number }\end{array}$ & Lubricated part & Lubrication method & Lubrication timing \\
\hline I & shaft bearings & lubricator & once every 3 months \\
\hline II & bolts & by drops & once every 3 months \\
\hline
\end{tabular}

\section{SUMMARY}

The performed basic model research and its analysis as well as the designed and created tank closing system fully met the assigned task during the mixer field tests. The proposed system allows for the precise regulation of the outlet slot, which makes it possible to achieve a material output with specific granulation. The proposed system allows us to precisely determine the balling performance. The use of bolt joints as connections (without using elastic elements) allowed us to obtain higher durability. In the late lifting and tilting device, a single cylinder was used, which greatly simplifies the control and regulation of the technological parameters of the mixer. During the operation of the device over an entire year, it has produced $70,000 \mathrm{Mg}$ of the product. This product has met customer expectations, and the device has not posed any serious operational problems.

\section{References}

[1] Dzik T., Hryniewicz M.: Research on pressure agglomeration of composite fuels, "Inżynieria i Aparatura Chemiczna" 2013 , 52, 3: 165-167.

[2] Feliks J.: Badania laboratoryjne granulowania mułów węglowych, "Chemik: Nauka - Technika - Rynek" 2012a, 66, 5: 388-395.
[3] Feliks J.: Performance tests of waste coal sludge granulation, "Polish Journal of Environmental Studies", 2012b, 21, 5A: 69-72.

[4] Feliks J.: Granulation of dolomite and limestone in the vibratory granulator, "Przemysł Chemiczny" 2015, 94, 5: 771-773.

[5] Feliks J., Mitura A., Marciniak-Kowalska J.: Analysis of possibilities of application of vibratory cluster producing device to alternative fuel production, "Polish Journal of Environmental Studies" 2013, 22, 6A: 12-17.

[6] Kuczyńska I.: Grudkowanie - forma przygotowania odpadów do wykorzystania lub unieszkodliwienia, "Chemik: Nauka Technika - Rynek" 2008, 61, 9: 434-435.

[7] Obraniak A.: Granulacja popiołów lotnych uzyskanych ze spalania węgla brunatnego, "Inżynieria i Aparatura Chemiczna" 2013, 52, 3: 213-215.

[8] Robak J., Matuszek K.: Granulowanie paliwa $z$ odpadów, "Chemik: Nauka - Technika - Rynek" 2012, 61, 9: 418-424.

[9] Sidor J., Feliks J.: Vibratory granulators, "Przemysł Chemiczny" 2015, 94, 5: 767-770.

[10] Feliks J.: Mechanizm zamykania dolnej pokrywy zbiornika obrotowego, zwłaszcza materiałów sypkich, Patent no. PL 224714 B1, 2013.

[11] Grabysz W.: Wybrane zagadnienia symboliczno-numerycznej symulacji mechanizmów, Wydawnictwo Politechniki Śląskiej, Katowice 2002.

JACEK FELIKS Ph.D., Eng. Department of Mining, Dressing and Transport Machines

Faculty of Mechanical Engineering and Robotics AGH University of Science and Technology al. Mickiewicza 30, 30-059 Kraków, Poland feliks@agh.edu.pl 


\title{
JACEK FELIKS
}

\section{Innowacyjne rozwiązanie mieszalnika mułów węglowych}

\begin{abstract}
$W$ trakcie wzbogacania wegla w zaktadach przeróbki mechanicznej powstaja drobnoziarniste muly węglowe o dużej wilgotności. Odpady te moga być wykorzystane w mieszankach energetycznych po obróbce mającej na celu obniżenie wilgoci. Dlatego też między innymi wykonuje się grudkowniki mułów węglowych.

W Katedrze Maszyn Górniczych, Przeróbczych i Transportowych powstat projekt prototypowej instalacji do grudkowania mułów węglowych o wydajności $50 \mathrm{Mg} / \mathrm{h}$. Zasadnicza częścia instalacji jest mieszalnik. $W$ dolnej części mieszalnika znajduje się otwór, który zamykany jest talerzem. W czasie pracy grudkownika talerz jest uchylony $i$ wykonuje ruch obrotowy wokót własnej osi. Rotacja bębna i mieszadet zainstalowanych wewnatrz mieszalnika powoduja rozdrabnianie mułu oraz jego homogenizację. Istotny dla prawidtowej eksploatacji mieszalnika jest prawidłowo działajacy układ zamykania bębna. Zaprojektowano układ, który pozwolit na opuszczanie talerza w pierwszym etapie wewnatrz otworu bębna ruchem prostoliniowym, a po wyprowadzeniu z otworu wysypu odchylenie o założony kąt. Projekt wymagat zbadania kinematyki uktadu i określenia obciażeń układu napędowego, co pozwoliło na wyznaczenie parametrów eksploatacyjnych. $W$ pracy przedstawiono tok postępowania, wyniki badan podstawowych wraz z ich analiza. Wykonano dobór optymalnych parametrów konstrukcyjnych i eksploatacyjnych na podstawie metody syntezy graficznej, stworzony model symulacyjny oraz badania prototypowego urzadzenia.
\end{abstract}

Słowa kluczowe: grudkowanie, aglomeracja, mieszalnik, paliwa alternatywne, muly weglowe, palety, granulacja, uktady zamykania zbiorników

\section{WSTĘP}

W trakcie procesów wzbogacania węgla w zakładach przeróbki mechanicznej kopalń węgla kamiennego powstają drobnoziarniste odpady przemysłowe o dużej wilgotności, zwane mułami węglowymi. Są to najdrobniejsze klasy ziarnowe o uziarnieniu poniżej $1 \mathrm{~mm}$, w których frakcje poniżej $0,035 \mathrm{~mm}$ stanowią nawet $60 \%$ udziału masowego. W zależności od parametrów jakościowych (zawartość popiołu i siarki, wartość opałowa itp.) muły te mogą być kierowane bezpośrednio do mieszanek energetycznych lub są deponowane w osadnikach ziemnych poszczególnych kopalń. Duża wilgotność powierzchniowa mułu, wynosząca po odwodnieniu na filtrach od $25 \%$ do $30 \%$ powoduje trudności przy wyładunku tego produktu z wagonów, zwłaszcza w okresie zimowym $\mathrm{z}$ uwagi na brak skutecznych tanich środków przeciwdziałających zamarzaniu. Najkorzystniejszym sposobem obniżenia zawartości wilgoci w mule węglowym jest oddziaływanie chemiczne, w wyniku którego zostaje obniżona wilgotność przemijająca mułu węglowego. Tak przygotowane mieszanki energetyczne można poddać procesowi aglomeracji ciśnieniowej [1] lub korzystniejszej ze względu na niższą energochłonność aglomeracji bezciśnieniowej (grudkowania) [2-9].

W Katedrze Maszyn Górniczych, Przeróbczych i Transportowych AGH powstał projekt prototypowej instalacji do grudkowania mułów węglowych (rys. 1) o wydajności $50 \mathrm{Mg} / \mathrm{h}$. 


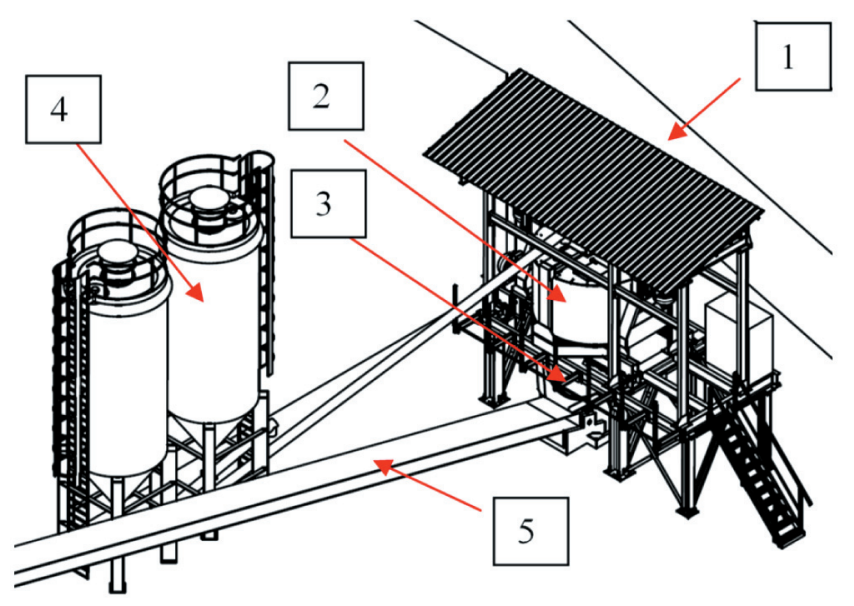

Rys. 1. Stacja do grudkowania mułów węglowych: 1 - układ podawania mułu węglowego, 2 - mieszalnik, 3 - grudkownik talerzowy, 4 - układ podawania dodatków wiążacych, 5 - taśmociag odprowadzajacy produkt

W skład instalacji do grudkowania mułu węglowego wchodzą następujące podzespoły:

- układ podawania mułów węglowych (1),

- mieszalnik (2),

- grudkownik talerzowy (3),

- układ podawania dodatków wiążących (4),

- układ odbioru produktu (5).

Zasadniczą częścią instalacji jest mieszalnik (rys. 2) zbudowany z bębna obrotowego o średnicy $2,7 \mathrm{~m}$ i wysokości 1,6 m, do którego podawany jest muł węglowy i dodatki wiążące (wapno palone). W bębnie zabudowane są dwa mieszadła posiadające niezależne napędy, mające za zadanie rozdrabnianie podawanego w kawałkach mułu oraz wymieszanie go z podawaną przenośnikiem ślimakowym z silosu substancją umożliwiającą obniżenie wilgotności mułu. W dolnej części bębna mieszalnika znajduje się otwór, którym wydostaje się materiał. Otwór ten zamykany jest talerzem. W czasie pracy grudkownika talerz jest uchylony i wykonuje ruch obrotowy wokół własnej osi.
Układ ten pomaga w rozładowaniu bębna oraz częściowo powoduje grudkowanie materiału.

Materiał po ustaleniu się procesu homogenizacji poprzez otwór w dnie bębna podawany jest na grudkownik talerzowy, na którym dochodzi do grudkowania materiału. Zgrudkowany materiał opuszczający grudkownik talerzowy podawany jest na przenośnik taśmowy, którym transportowany jest na plac składowy. Konstrukcja stacji umożliwia dodawanie innych komponentów do wytwarzanych mieszanek paliwowych na bazie mułu czy miału węglowego.

Istotny dla poprawnej eksploatacji układu mieszania jest prawidłowo działający układ zamykania zbiornika. W założeniu układ ten powinien zamykać szczelnie zbiornik, a po otwarciu talerz układu zamykającego powinien wychylić się o określony kąt wynoszący do $30^{\circ}$. Układ łożyskowania bębna ogranicza wielkość otworu wylotowego do $730 \mathrm{~mm}$. Średnica ta ogranicza wielkość talerza zamykającego. W celu poprawnej eksploatacji układu talerz zamykający powinien zmniejszać przestrzeń wysypu materiału (zmniejszenie ryzyka powstawania nawisów mułu).
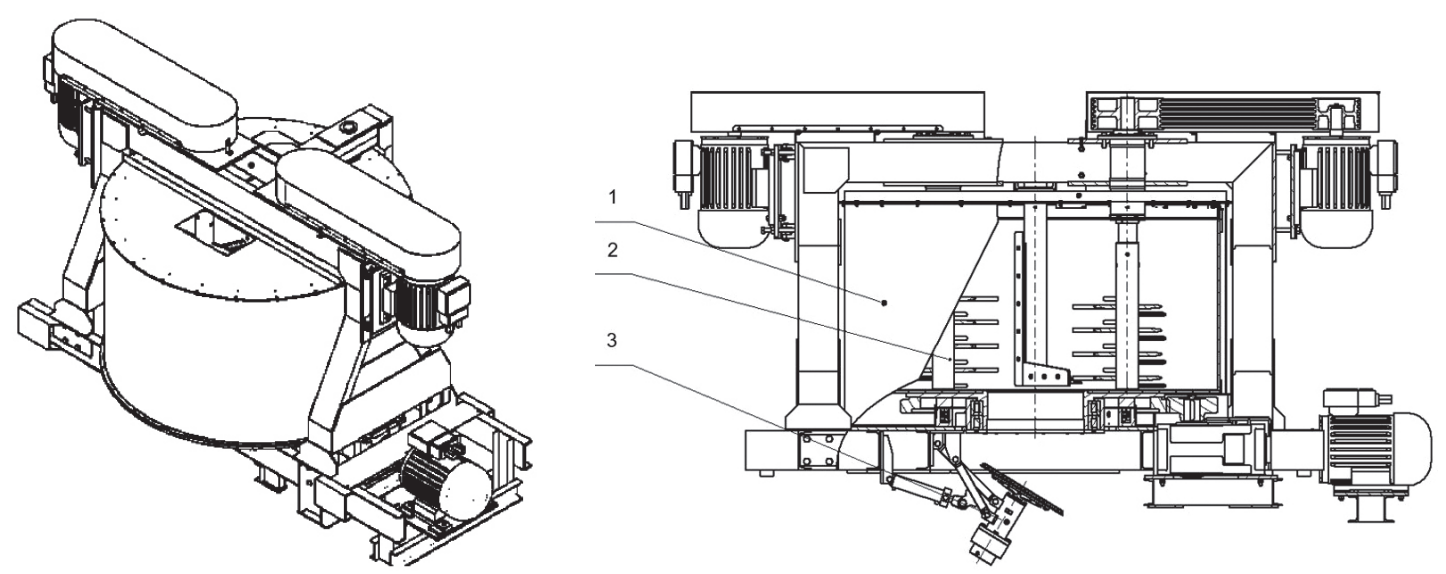

Rys. 2. Mieszalnik mułów węglowych: 1 - bęben, 2 - układ mieszadeł, 3 - układ zamykania bębna 
Wysokość tej przestrzeni przy założonej średnicy nie powinna przekraczać $200 \mathrm{~mm}$. W przypadku mieszalnika konstrukcji AGH powoduje to konieczność wprowadzania talerza zamykającego na głębokość co najmniej $125 \mathrm{~mm}$. Powyższe wymogi spowodowały konieczność zaprojektowania układu, który pozwoliłby na opuszczanie talerza $\mathrm{w}$ pierwszym etapie wewnątrz bębna ruchem prostoliniowym, a po wyprowadzeniu $\mathrm{z}$ otworu wysypu odchylenie o założony kąt.

\section{WYZNACZENIE PARAMETRÓW UKŁADU KINEMATYCZNEGO RAMION}

Znając założenia konstrukcyjne (średnicę talerza $730 \mathrm{~mm}$, przesunięcie względem podstawy bębna min. $125 \mathrm{~mm}$, maksymalny kąt wychylenia talerza $30^{\circ}$ ), zaproponowano układ czworoboku przegubowego, w którym ramiona $(R, r)$ są różnych długości i w pozycji podniesionej do siebie równoległe [10]. Pierwszym etapem było dobranie odpowiedniej długości ramion tak, aby nie następowała kolizja pomiędzy talerzem a otworem w bębnie miksera. W konstrukcji miksera przewidziano luz pomiędzy talerzem a otworem bębna wynoszący $15 \mathrm{~mm}$ pozwalający na swobodne wysunięcie talerza zamykającego.

\subsection{Geometryczne wyznaczenie długości ramion}

Wstępnie dobrano długości, wykorzystując metodę syntezy graficznej czworoboku przegubowego realizującego przejście przez trzy zadane położenia (rys. 3).

Na rysunku 3 pokazano układ ramion analizowanego mechanizmu zgodnie ze wstępnie przyjętymi założeniami. Przesunięcie talerza względem otworu (punkt T1) nie przekracza założonych $15 \mathrm{~mm}$. $\mathrm{Z}$ analizy wynika, że ramię górne powinno mieć większą długość od ramienia dolnego. Dobrano długość ramienia górnego wynoszącą $620 \mathrm{~mm}$, a ramienia dolnego - $480 \mathrm{~mm}$.

\subsection{Weryfikacja poprawności działania układu}

Zaproponowany czworobok przegubowy (rys. 3) pozwolił na stworzenie płaskiego modelu układu zamykania pozwalającego przeanalizować kinematykę (rys. 4) [11].

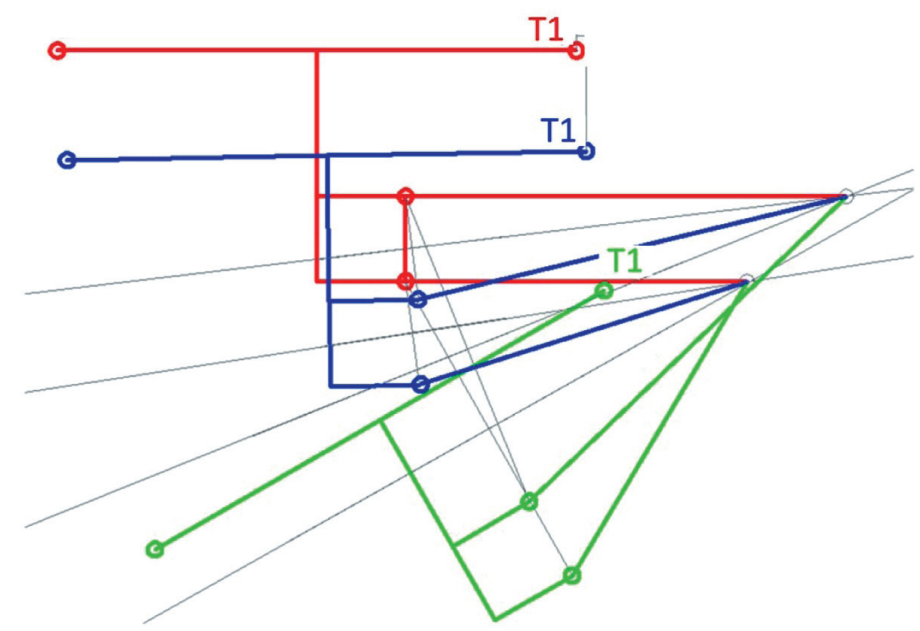

Rys. 3. Analiza czworoboku przegubowego realizującego przejście przez trzy położenia: czerwone - bęben zamknięty, niebieskie - talerz w pozycji dolnej ptaszczyzny bębna, zielone - maksymalne otwarcie i wychylenie talerza

a)

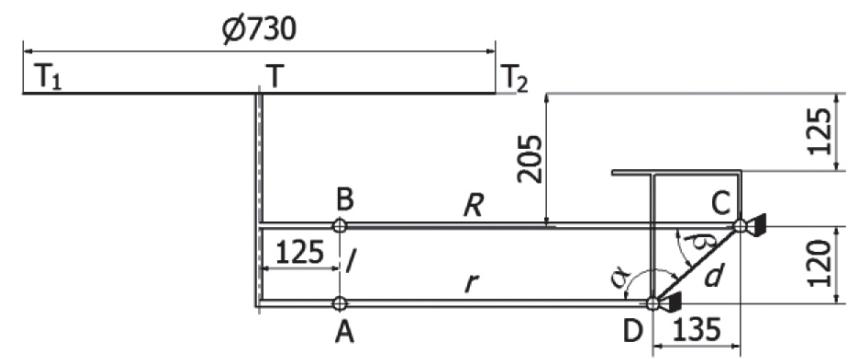

b)

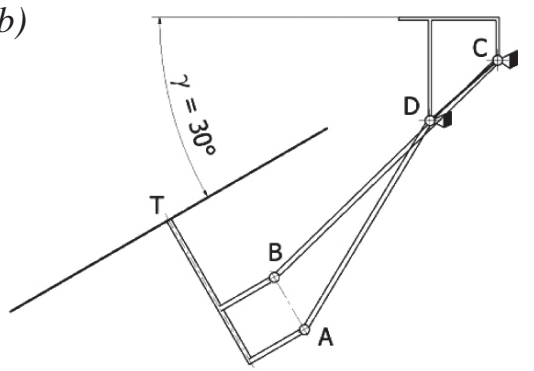

Rys. 4. Model płaski układu zamykania: a) talerz w pozycji podniesionej; b) talerz w pozycji opuszczonej 
Założono, że układ napędzany jest siłownikiem hydraulicznym dwustronnego działania wywołującego obrót ramienia AD. Punktem wyjścia do rozwiązania kinematyki jest równanie wektorowe:

$$
\overline{D A}+\overline{A B}+\overline{B C}=\overline{C D}
$$

gdzie długości wektorów:

$$
R=\overline{B C}, \quad r=\overline{A D}, \quad l=\overline{A B}, \quad d=\overline{C D},
$$

czyli:

$$
\overline{D A}=\left[\begin{array}{c}
r \cos \alpha \\
r \sin \alpha
\end{array}\right], \quad \overline{B C}=\left[\begin{array}{c}
R \cos \beta \\
-R \sin \beta
\end{array}\right], \quad \overline{C D}=\left[\begin{array}{l}
d \\
0
\end{array}\right],
$$

można zatem zapisać:

$$
\overline{A B}^{T} \cdot \overline{A B}=l^{2}
$$

po rozwinięciu:

$$
(R \sin \beta-r \sin \alpha)^{2}+(d-R \cos \beta-r \cos \alpha)^{2}=l^{2}
$$

układ będzie wychylany za pomocą ramienia $r$, stąd też zakładamy dany kąt $\alpha$.

W dalszych rozważaniach podstawiamy:

$$
p=\operatorname{tg} \frac{1}{2} \beta
$$

równanie (3) po zastosowaniu podstawienia (4) i zależności algebraicznych dla połowy kąta przyjmuje postać:

$$
\left(R \frac{2 p}{p^{2}+1}-r \sin \alpha\right)^{2}+\left(d-R \frac{\left(1-p^{2}\right)}{p^{2}+1}-r \cos \alpha\right)^{2}=l^{2}
$$

Równanie to ma dwa rozwiązania, z których wybieramy jedno odpowiadające geometrii (rys. 4):

$$
\beta=\operatorname{arctg} \frac{\sqrt{K}+2 R r \sin \alpha}{R^{2}+2 R d-2 R r \cos \alpha+d^{2}-2 d r \cos \alpha-l^{2}+r^{2}}
$$

gdzie:

$$
\begin{aligned}
K & =-R^{4}-d^{4}-l^{4}-r^{4}+2 R^{2} d^{2}+ \\
& +2 R^{2} l^{2}+2 R^{2} r^{2}+2 d^{2} l^{2}-4 d^{2} r^{2}+ \\
& +2 l^{2} r^{2}-2 d^{2} r^{2} \cos 2 \alpha+ \\
& +4 d r\left(-R^{2}+d^{2}-l^{2}+r^{2}\right) \cos \alpha
\end{aligned}
$$

Znając wartość kąta $\beta$, możemy określić położenie punktów A i B oraz wartość kąta $\gamma$, co pozwala wyznaczyć trajektorię punktu $\mathrm{T}$. Na rysunku 5 przedstawiono przykładowy wykres położenia punktów A, B oraz T przy założonym środku układu współrzędnych w punkcie $\mathrm{C}$ i osiach $\mathrm{x}$ poziomo i y pionowo.

Aby nie następowała kolizja talerza $\mathrm{z}$ bębnem mieszalnika, istotne jest, aby punkt T2 (rys. 4) przy przesunięciu y o $125 \mathrm{~mm}$ nie powodował większego niż przewidziany luz przemieszczenia wzdłuż osi $\mathrm{x}$. W celu weryfikacji założeń sporządzono wykres położenia trzech charakterystycznych punktów talerza (T, $\mathrm{T}_{1}, \mathrm{~T}_{2}$ ) (rys. 6).

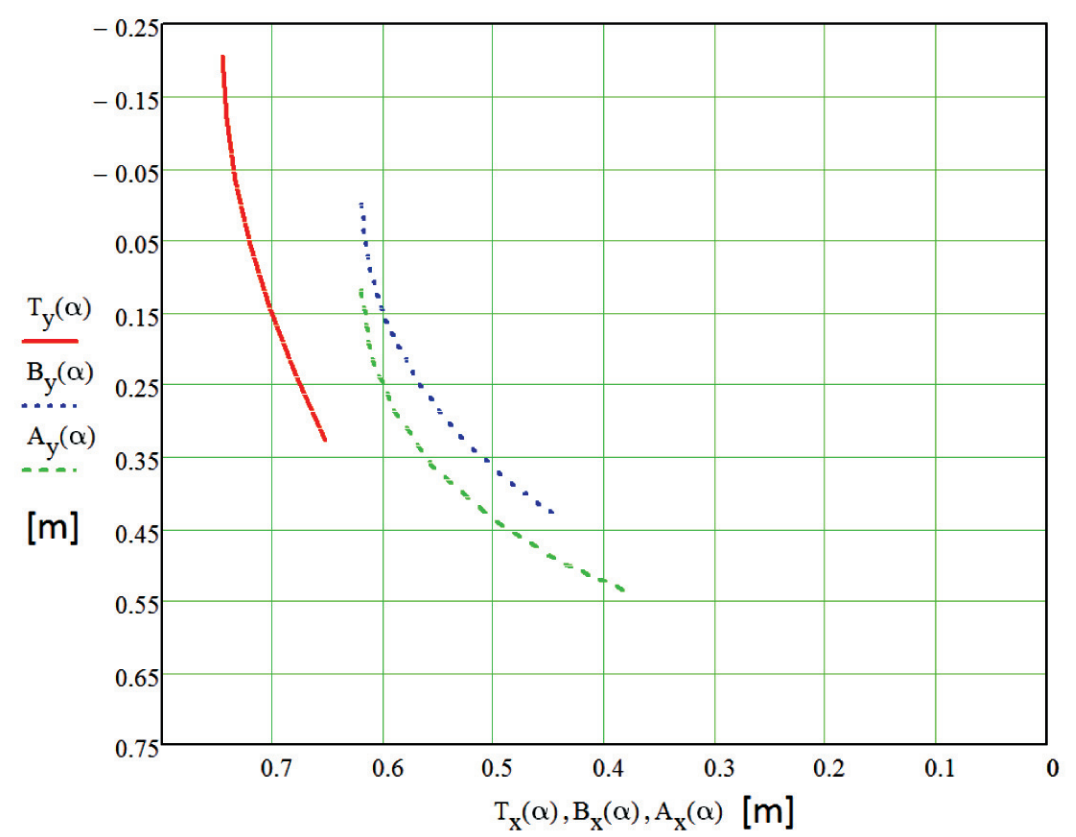

Rys. 5. Przykładowe trajektorie punktów A, B i Tw zależności od kąta wychylenia ramienia $A D(\alpha)$ 


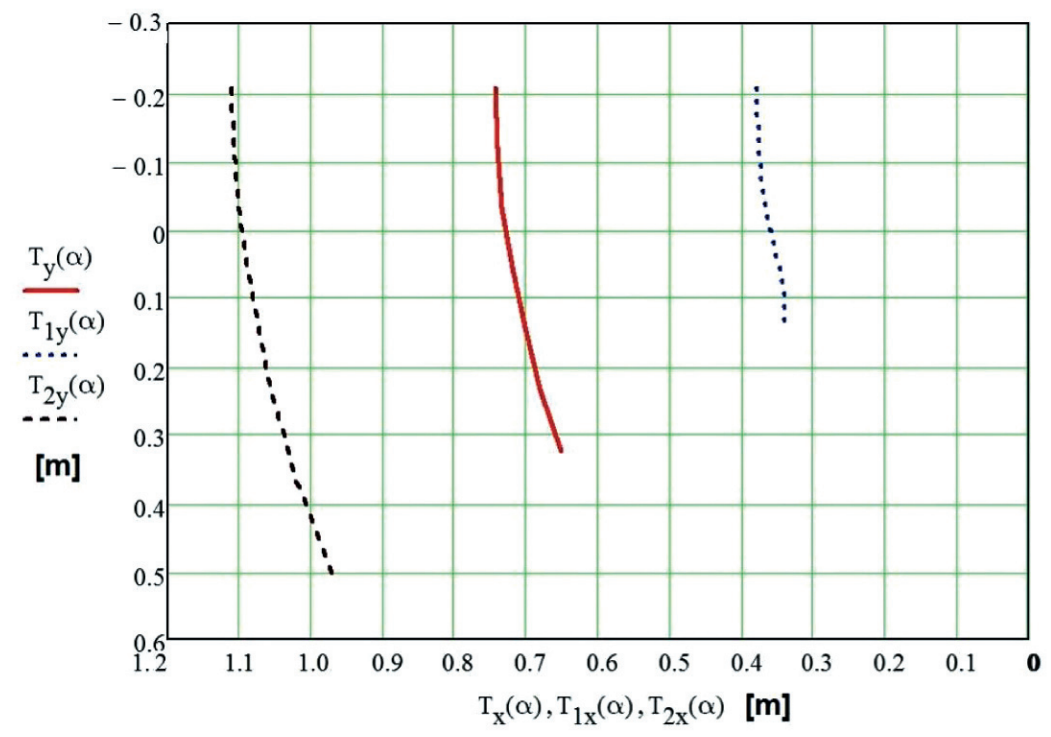

Rys. 6. Trajektorie trzech charakterystycznych punktów talerza

Analiza położeń wykazała, że taki układ kinematyczny spełnia wymogi wobec konstrukcji. Określono również kąt $\alpha$, o jaki należy obrócić ramię dolne, aby uzyskać wychylenie talerza o $30^{\circ}$. Kąt ten wyniósł $58^{\circ}$. Następnym etapem prac było stworzenie modelu układu zamykania (rys. 7) uzupełnionego o układ napędu talerza.

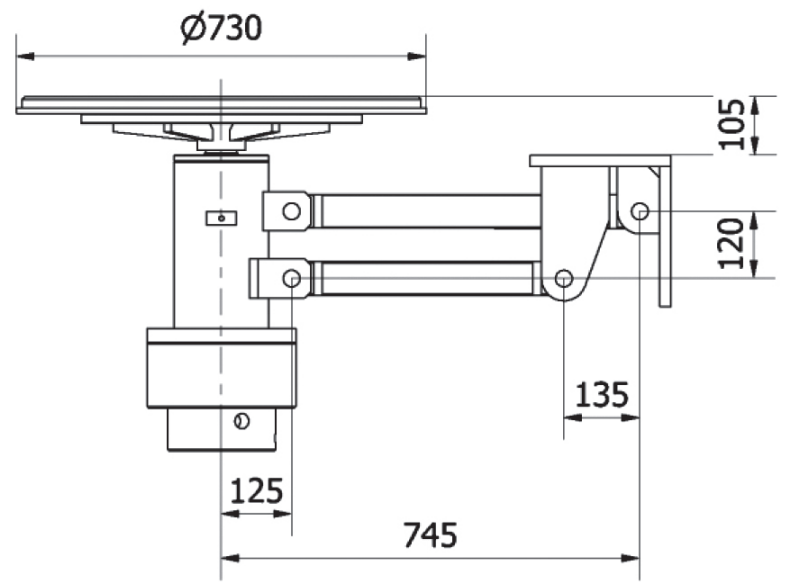

Rys. 7. Model układu zamykania bębna z układem napędu talerza
Do napędu talerza dobrano silnik hydrauliczny o następujących parametrach:

- chłonność jednostkowa silnika: $1000 \mathrm{~cm}^{3} / \mathrm{obr}$,

- ciśnienie nominalne: $16 \mathrm{MPa}$,

- ciśnienie maksymalne: $25 \mathrm{MPa}$,

- moment obrotowy nominalny: $2500 \mathrm{Nm}$,

- maksymalna prędkość obrotowa: 160 obr/min,

- praca przy założonej prędkości obrotowej w zakresie: $30-50$ obr/min.

\subsection{Weryfikacja modelu dla założonych parametrów konstrukcyjnych}

Do prawidłowej eksploatacji układu istotne jest odpowiednie zaprojektowanie układu podnoszenia ramienia dolnego. Założono, że do napędu ramienia dolnego zostanie wykorzystany siłownik hydrauliczny. Stworzony model układu zamykania uzupełniono o siłownik hydrauliczny, który zamontowano na dodatkowym uchwycie (rys. 8).

W przypadku takiego układu skok tłoka siłownika hydraulicznego, określony na podstawie analizy kinematyki, powinien wynosić co najmniej $220 \mathrm{~mm}$. Na tej podstawie dobrano siłownik hydrauliczny o skoku $230 \mathrm{~mm}$. a)

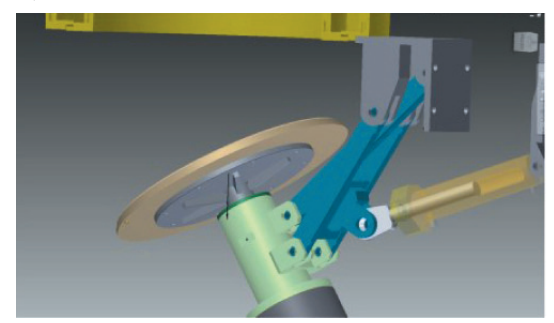

b)

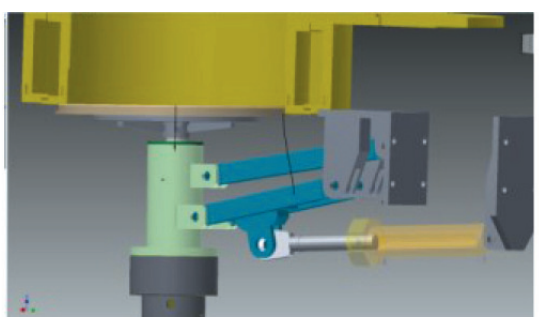

c)

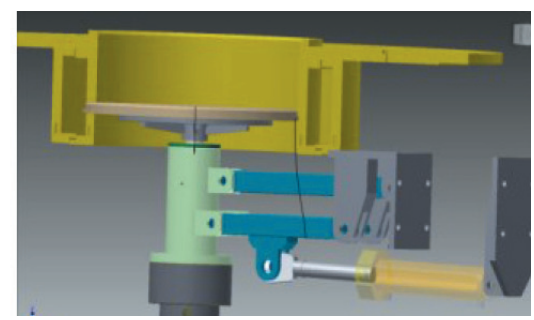

Rys. 8. Model układu zamykania w trzech pozycjach: a) otwartej;

b) na styku z dolna powierzchnia bębna; c) zamkniętej 


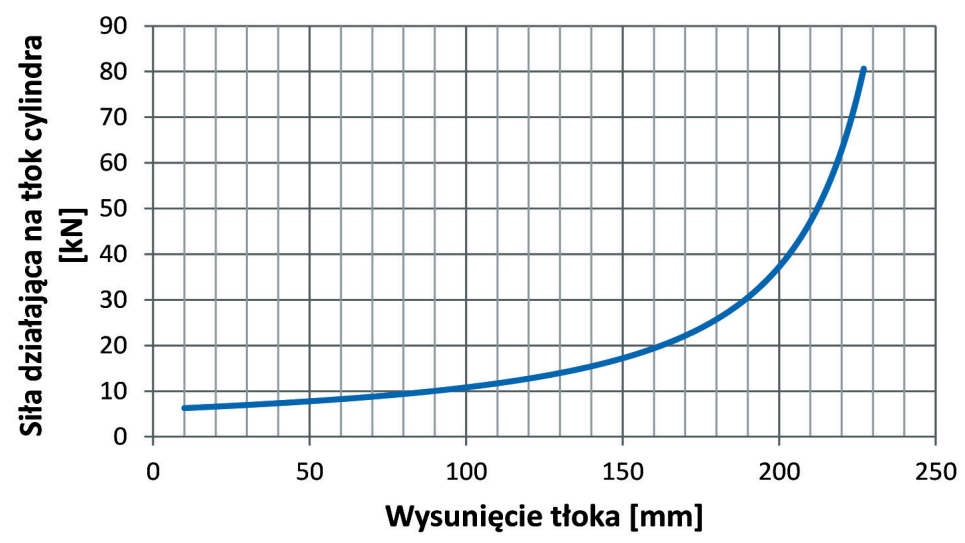

Rys. 9. Ilustracja przebiegu wartości sity dziatającej na ttok cylindra

W celu określenia pozostałych parametrów siłownika hydraulicznego poddano ten układ analizie dynamicznej. Na jej podstawie wyznaczono siły działające na tłok siłownika przy założeniu maksymalnego obciążenia talerza materiałem o masie $150 \mathrm{~kg}$. W trakcie analizy założono stałą prędkość wysuwu tłoka. Na podstawie symulacji sporządzono wykres siły działającej na tłok w zależności od stopnia jego wysunięcia (rys. 9).

Maksymalna wartość siły działającej na tłok wystąpi w chwili zamknięcia bębna i wyniesie ona $80 \mathrm{kN}$. Dla zaprojektowanej konstrukcji układu podnoszenia klapy dobrano siłownik hydrauliczny klapy zamykającej o następujących parametrach:

- element napędowy: siłownik hydrauliczny $\varnothing 80 / 45$ dwustronnego działania z jednostronnym tłoczyskiem, zakończony przegubami kulistymi mocującymi,

- pole powierzchni kołowej czynnej tłoka: 50,30 $\mathrm{cm}^{2}$,

- pole powierzchni pierúcieniowej czynnej tłoka: $34,4 \mathrm{~cm}^{2}$,

- skok tłoka - $230 \mathrm{~mm}$,

- stała prędkość wysuwania tłoczyska: ok. 4,9 cm/s,

- nastawiana prędkość wsuwania tłoczyska: maks. ok. $7,1 \mathrm{~cm} / \mathrm{s}$,

- maksymalna siła pchania: ok. $80 \mathrm{kN}($ dla $p=16 \mathrm{MPa})$,

- wymagana siła pchania podczas wysuwu tłoczyska: $70 \mathrm{kN}$ (dla $p=13,9 \mathrm{MPa})$,

- maksymalna siła ciągnięcia: ok. $55 \mathrm{kN}$ (dla $p=16 \mathrm{MPa}$ ),

- wymagana siła opuszczania klapy podczas wsuwu tłoczyska: $25 \mathrm{kN}(p \approx 5,0 \mathrm{MPa})$.

a)

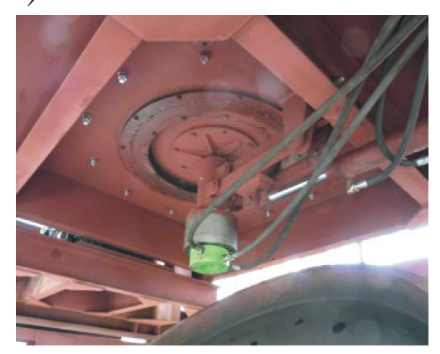

3. BADANIA EKSPLOATACYJNE UKŁADU ZAMYKANIA

Na podstawie sporządzonej dokumentacji wykonano prototypowe urządzenie do grudkowania mułów węglowych z zaproponowanym układem zamykania zbiornika. Pierwszym etapem badań eksploatacyjnych urządzenia było sprawdzenie poprawności przemieszczania talerza. Na rysunku 10 pokazano zdjęcia z badań.

W trakcie otwierania i zamykania bębna nie następowała kolizja pomiędzy talerzem klapy zamykającej a bębnem (rys. 10b). Badania pokazały prawidłowo dobraną długość ramion i miejsca ich zamocowania. Siłownik pracował poprawnie i nie następowało przekroczenie jego parametrów technicznych.

\section{UWAGI EKSPLOATACYJNE}

Prawidłowa praca zespołu obrotowego talerza uwarunkowana jest zapewnieniem odpowiedniego smarowania. Podczas montażu wszystkie sworznie oraz współpracujące powierzchnie przegubów należy pokryć smarem grafitowym. Na rysunku 11 zaznaczono punkty smarowania zespołu. $\mathrm{W}$ tabeli 1 podano miejsce oraz sposób smarowania, rodzaj smaru i czasookres smarowania.

b)

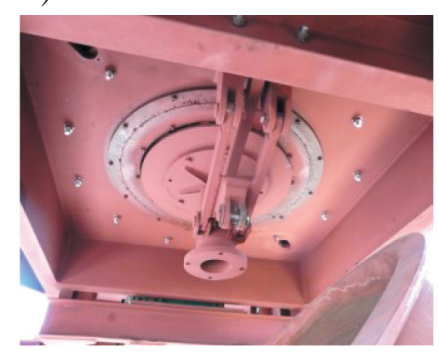

c)

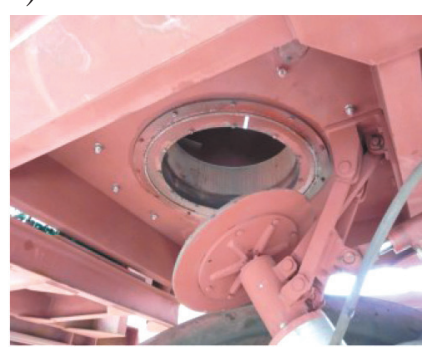

Rys. 10. Układ zamykania mieszalnika: a) w pozycji zamkniętej; b) w pozycji pośredniej; c) w pozycji otwartej 


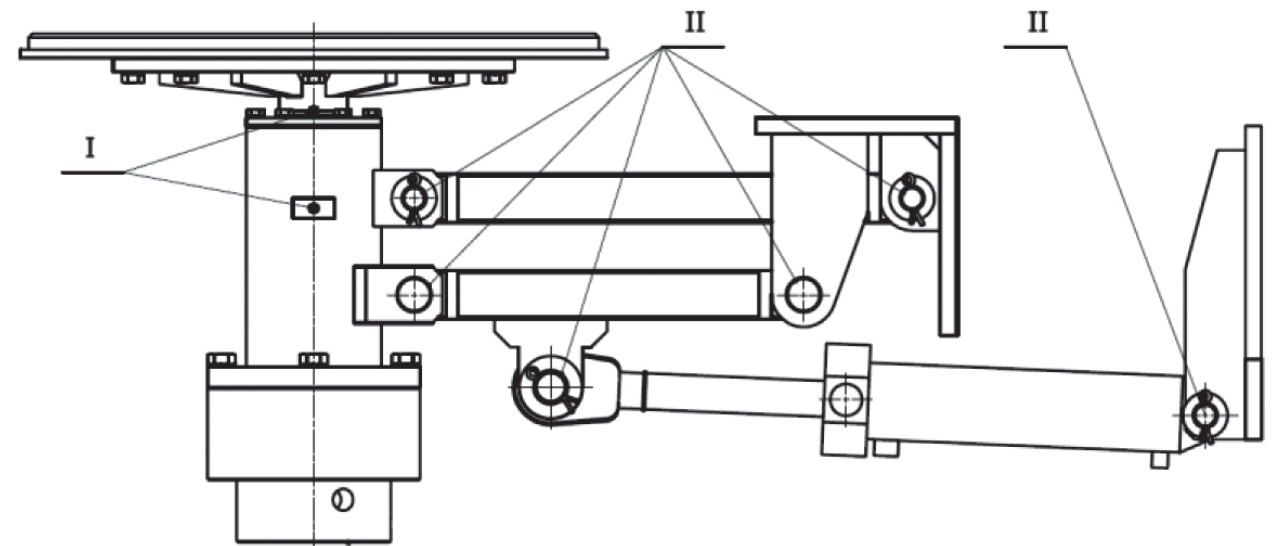

Rys. 11. Rozmieszczenie punktów smarowania w zespole obrotowym talerza

Tabela 1

Miejsca oraz sposób smarowania zespołu obrotowego talerza

\begin{tabular}{|c|c|c|c|}
\hline $\begin{array}{c}\text { Nr miejsca } \\
\text { smarowania }\end{array}$ & Części smarowane & Sposób smarowania & Minimalny czasookres \\
\hline I & łożyska wału & smarownica & raz na 3 miesiące \\
\hline II & sworznie & kroplowo & raz na 3 miesiące \\
\hline
\end{tabular}

\section{PODSUMOWANIE}

Przeprowadzone podstawowe badania modelowe oraz ich analiza, a także zaprojektowany i wykonany układ zamykania zbiornika podczas badań eksploatacyjnych mieszalnika w pełni sprostał powierzonemu zadaniu. Zaproponowany układ pozwala na precyzyjną regulację szczeliny wylotowej, dzięki czemu uzyskujemy wysyp materiału o określonej granulacji. Układ ten umożliwia precyzyjne ustalenie wydajności grudkownika. Zastosowanie sworzniowych połązeń przegubów (brak elementów elastycznych) pozwoliło na uzyskanie wyższej trwałości konstrukcji. W urządzeniu do podnoszenia i odchylania talerza wykorzystano pojedynczy siłownik, co w znacznym stopniu upraszcza sterowanie i regulację parametrów technologicznych mieszalnika. W trakcie eksploatacji urządzenia w roku 2013 wytworzono 70 tys. Mg produktu. Produkt ten spełniał oczekiwania odbiorców, a urządzenie nie stwarzało poważnych problemów eksploatacyjnych.

\section{Literatura}

[1] Dzik T., Hryniewicz M.: Research on pressure agglomeration of composite fuels, „Inżynieria i Aparatura Chemiczna” 2013 , 52, 3: 165-167.

[2] Feliks J.: Badania laboratoryjne granulowania mułów węglowych, „Chemik: Nauka - Technika - Rynek” 2012, 66, 5: 388-395.
[3] Feliks J.: Performance tests of waste coal sludge granulation, „Polish Journal of Environmental Studies”, 2012, 21, 5A: 69-72.

[4] Feliks J.: Granulation of dolomite and limestone in the vibratory granulator, „Przemysł Chemiczny” 2015, 94, 5: 771-773.

[5] Feliks J., Mitura A., Marciniak-Kowalska J.: Analysis of possibilities of application of vibratory cluster producing device to alternative fuel production, „Polish Journal of Environmental Studies" 2013, 22, 6A: 12-17.

[6] Kuczyńska I.: Grudkowanie - forma przygotowania odpadów do wykorzystania lub unieszkodliwienia, „Chemik: Nauka Technika - Rynek" 2008, 61, 9: 434-435.

[7] Obraniak A.: Granulacja popiołów lotnych uzyskanych ze spalania węla brunatnego, „Inżynieria i Aparatura Chemiczna” 2013, 52, 3: 213-215.

[8] Robak J., Matuszek K.: Granulowanie paliwa z odpadów, „Chemik: Nauka - Technika - Rynek” 2012, 61, 9: 418-424.

[9] Sidor J., Feliks J.: Vibratory granulators, „Przemysł Chemiczny" 2015, 94, 5: 767-770.

[10] Feliks J.: Mechanizm zamykania dolnej pokrywy zbiornika obrotowego, zwłaszcza materiałów sypkich, Patent nr PL 224714 B1, 2013.

[11] Grabysz W.: Wybrane zagadnienia symboliczno-numerycznej symulacji mechanizmów, Wydawnictwo Politechniki Śląskiej, Katowice 2002.

dr inż. JACEK FELIKS

Katedra Maszyn Górniczych, Przeróbczych $i$ Transportowych Wydziat Inżynierii Mechanicznej i Robotyki AGH Akademia Górniczo-Hutnicza im. Stanisława Staszica w Krakowie al. Mickiewicza 30, 30-059 Kraków feliks@agh.edu.pl 